\title{
Neterpimost' $v$ Rossii, starye i novye fobii. Moscou, Moskovskij centr Karnegi, 1999, 196 p. [L'intolérance en Russie, anciennes et nouvelles phobies]
}

\section{Stéphane A. Dudoignon}

\section{(2) OpenEdition}

\section{Journals}

Édition électronique

URL : http://journals.openedition.org/abstractairanica/37234

DOI : 10.4000/abstractairanica.37234

ISSN : 1961-960X

Éditeur :

CNRS (UMR 7528 Mondes iraniens et indiens), Éditions de l'IFRI

Édition imprimée

Date de publication : 15 mai 2001

ISSN : 0240-8910

\section{Référence électronique}

Stéphane A. Dudoignon, « Neterpimost' v Rossii, starye i novye fobii. Moscou, Moskovskii centr Karnegi, 1999, 196 p. [L'intolérance en Russie, anciennes et nouvelles phobies] », Abstracta Iranica [En ligne], Volume 22 | 2001, document 600, mis en ligne le 17 février 2010, consulté le 13 octobre 2020. URL http://journals.openedition.org/abstractairanica/37234; DOI : https://doi.org/10.4000/ abstractairanica.37234

Ce document a été généré automatiquement le 13 octobre 2020.

Tous droits réservés 


\title{
Neterpimost' $v$ Rossii, starye i novye fobii. Moscou, Moskovskij centr Karnegi, 1999, 196 p. [L'intolérance en Russie, anciennes et nouvelles phobies]
}

\author{
Stéphane A. Dudoignon
}

1 À la suite de quelques premières études sur la montée de l'«islamophobie » dans la Fédération de Russie (voir en particulier A. V. Kudrjavcev, «Islamofobija v postsovetskoj Rossii » [L'islamophobie en Russie post-soviétique], dans Islam v SNG [L'islam dans la CEI], éd. A. Malašenko, Moscou, Institut vostokovedenija RAN, 1998, pp. 160-172; c.r. dans Abs.Ir., 20-21, $\mathrm{n}^{\circ} 468$ ), le présent recueil s'étend plus particulièrement sur la manière dont les peuples caucasiens, mais aussi les juifs, sont perçus en Russie depuis la fin de la première guerre avec la Tchétchénie (1994-1996). Parmi les études de cas les plus intéressantes, signalons celle consacrée à l'évolution récente de la perception des migrants du Caucase par la population russe d'Irkoutsk, en Sibérie orientale (Viktor Djatlov, « Kavkazcy v Irkutske : konfliktogennaja diaspora » [Les Caucasiens à Irkoutsk: une diaspora source de conflits], pp.113-135). Dans un esprit qui est celui de tout le recueil, l'A. de cette étude souligne judicieusement le très grand écart entre l'implication réelle de ces communautés migrantes 區 azérie, en particulier 㡠 dans l'économie parallèle d'Irkoutsk et de sa région, et la manière dont elles sont perçues par la population locale comme un facteur de déstabilisation et d'insécurité. Dans une étude plus générale, on aborde le problème de l'instrumentalisation politique de la religion en Russie, et la diffusion d'un discours d'intolérance sur un très vaste spectre de l'éventail politique russe, en particulier dans

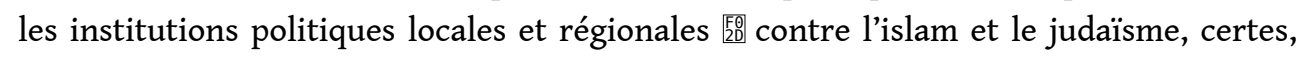
mais aussi, de plus en plus, contre les missions protestantes américaines (Sergej Filatov; Roman Lunkin, « Konec 90-x : vozroždenie religioznoj neterpimosti » [Fin des années 1990 : la renaissance de l'intolérance religieuse], pp. 136-150). Un dernier article 
est consacré à l'évolution très rapide, en Russie, de l'interaction entre les populations locales et les communautés migrantes issues des exodes récents de populations russes en provenance du Caucase ou d'Asie centrale ; l'A. note avec satisfaction l'apparition rapide de sentiments de solidarité à l'échelle locale, ce qui se traduit notamment par une imbrication croissante des communautés autochtones et migrantes dans les organisations d'assistance aux plus démunis (Galina Vitkovskaja, "Vynuždennaja migracija i migrantofobija v Rossii » [Migration forcée et migrantophobie en Russie], pp. 151-191, 34 tab.).

INDEX

Thèmes : 12.3. Asie centrale

\section{AUTEURS}

STÉPHANE A. DUDOIGNON

CNRS - Strasbourg 